\title{
Desire for birth spacing or limiting and non-use of long acting and permanent contraceptive methods among married women of reproductive age in Aksum Town, North Ethiopia
}

Kebede Haile ${ }^{1}$, Meresa Gebremedhin ${ }^{1 *}$, Haileselasie Berhane ${ }^{1}$, Tirhas Gebremedhin ${ }^{1}$, Alem Abraha ${ }^{1}$, Negassie Berhe ${ }^{1}$, Tewodros Haile ${ }^{2}$, Goitom Gigar ${ }^{3}$ and Yonas Girma ${ }^{4}$

\begin{abstract}
Background: Long acting and permanent contraceptive methods are the most effective family planning (FP) methods to prevent pregnancy and thereby averting adverse consequences of too many and ill-timed pregnancies. However, long acting and permanent contraceptive methods (LAPMs) are underutilized in Ethiopia for little documented reasons. Therefore, this study is aimed to assess magnitude and factors associated with desire for birth spacing for at least 2 years or limiting child bearing and non-use of LAPMs among married women of reproductive age in Aksum town, Northern Ethiopia.

Methods: A community-based cross-sectional study was conducted in Aksum town, North Ethiopia from May to June, 2015 among 779 randomly selected married women of reproductive age. Data were collected using interviewer administered pre-tested questionnaire. Data were entered using Epi-Info version 6.04 and exported to SPSS version 16 for analysis. Multivariate logistic regression models were fitted to identify factors associated with desire for birth spacing or limiting and not using LAPMs.

Results: The total desire for birth spacing or limiting was $69 \%$ and amongst those women $85.2 \%$ were not using LAPM. Education, occupation, husband's attitude towards LAPMs, age, number of pregnancy, regular media exposure and decider on the number of children to bear were significantly associated with desire for birth spacing or limiting. Moreover; education, occupation, husband's attitude towards LAPMs, discussion on family planning with husband, knowledge, attitude and intention to use LAPMs were significantly associated with not using LAPMs.
\end{abstract}

Conclusion: Desire for birth spacing or limiting and not using LAPMs is very high in the study area. Therefore, increasing access to family planning information and services with special emphasis on LAPMs and male involvement in the program are very important.

Keywords: Desire for birth spacing or limiting, Non-use of LAPMs, Aksum, Ethiopia

* Correspondence: mere2010ec@yahoo.com

${ }^{1}$ College of Health Science, Aksum University, P.O. Box 1010, Aksum, Ethiopia

Full list of author information is available at the end of the article 


\section{Background}

Long-acting and permanent methods of contraception (LAPMs) are modern family planning (FP) methods that prevent pregnancy for three or more years per application. LAPMs include intrauterine contraceptive devices (IUCDs), implants, female sterilization, and male sterilization [1]. LAPMs are safe, cost effective, convenient for users and 3-60 times more effective in preventing pregnancy than short acting methods (pills, injectable hormones and condoms) during a year of typical use [2, 3]. Effective contraceptive could prevent as many as one in every three maternal deaths by allowing women to delay motherhood, space births, avoid unintended pregnancies and abortions, and stop childbearing when they have reached their desired family size [4].

In the developing region, $57 \%$ of the 1.6 billion women of reproductive age desire to space births for at least 2 years or to limit childbearing at all [5]. Satisfying this total demand for contraception could prevent 52 million unintended pregnancies per year which would result in 500,000 fewer new born deaths and 70,000 fewer maternal deaths each year from the current status. However, about $26 \%$ the total women who desire to space or limit births in developing region and $58 \%$ in sub-Saharan Africa lack access to the modern methods of contraception [5, 6]. Even among the users of modern contraception methods, short acting methods of contraception, the less effective methods, are widely used (27 \%) [2, 3, 5, 7, 8]. Furthermore, about 20-30\% of women who use short acting methods of contraception stop within 2 years of starting due to health concerns. Many of these women could benefit from switching to LAPMs [9].

In the case of Ethiopia, nearly $75 \%$ of married women of reproductive age desire to space births for at least two years or to limit childbearing at all but not more than $5 \%$ are using LAPMs [10]. Moreover, Ethiopia continues to be one of the most populous countries in the world with a total population of 87.1 million and total fertility rate of 4.8 children per reproductive age group women [11]. According to Ethiopian Demographic and Health Survey (EDHS) report, Ethiopia is one of the SubSaharan Africa countries with the highest maternal mortality (676 per 100,000 live births) and neonatal mortality (37 per 1,000 live births) rates [10].

Therefore, to solve the aforementioned health problems in particular and to achieve the development goals in general, it is crucial to promote desire to space or limit births and let all women who desire to space or limit births access to LAPMs. Different factors may contribute to low desire for birth spacing or limiting and high non-use of LAPMs. As indicated by some studies conducted elsewhere; socio- demographic characteristics, reproductive health characteristics, knowledge, attitude, myths and misconceptions may affect desire for birth spacing or limiting and contribute to non-use of LAPMs [12-29].

Given the prevailing low utilization of LAPMs in Ethiopia, analysis of desire for birth spacing or limiting and non-use of LAPMs and a critical assessment of the underlying factors are very important. This information would have an important role in designing effective programs to heighten desire for birth spacing or limiting and reduce the prevailing high non-use of LAPMs. However, little has been documented so far in Ethiopia with regard to the aforementioned issues. Thus, this study is aimed to assess the magnitude and factors associated with desire for birth spacing for at least 2 years or limiting child bearing and non-use of LAPMs among married women of reproductive age in Aksum town, Northern Ethiopia.

\section{Methods \\ Study design and setting}

This community based cross sectional study was conducted from May to June, 2015 among married women of reproductive age (15-49 years) in Aksum town. Aksum town is located in the northern part of Ethiopia between 14, $1297\left(147^{\prime} 46.920\right.$ ”N) latitude and 38, 7158 (3842'56.880"E) longitude at a distance of $1010 \mathrm{~km}$ away from Addis Ababa. According to the 2007 report of Central Statistical Agency of Ethiopia, the total population of Aksum town is 60,766, with 30,991 (51.0 \%) females and 29,775 (49.0\%) males. Administratively the town is divided in to four Kebeles (small local administrative units) [30].

\section{Sample size and sampling procedure}

The sample size was determined using a single population proportion formula assuming; $95 \%$ level of confidence, proportion of women who desire to space or limit births of $50 \%$, a design effect of 2 and nonresponse rate of $5 \%$. This gave a final sample size of 806 married women of reproductive age. A two-stage sampling approach was used; where first 2 kebeles were selected randomly from the total 4 kebeles of Aksum town. In the selected kebeles, census was done to identify households where married women of reproductive age live. Then, the total sample size was allocated to each of the randomly selected kebeles based on probability proportional to size allocation. Secondly, using the sampling frame from the census of each respective kebele, 806 women who fulfilled the inclusion criteria were selected by simple random sampling technique. In case of absence of the eligible woman in the selected household, repeated attempts were made to get the woman. If the respondent could not be interviewed after 3 attempts, the woman was considered as non- 
respondent. When two or more married women were in a selected household, only one of them was considered by lottery method to participate in the study, to avoid intra-class correlation. Eventually, a total of 779 women were participated in this study.

\section{Measurement}

Data were collected using interviewer administered structured questionnaire adapted from different literatures $[10,12-14,19,31]$. The questionnaire was translated and contextualized to the local situation. The contents of the questionnaire included: sociodemographic factors, sexual and reproductive characteristics, knowledge, attitude and practice of family planning methods. Prior to data collection, the questionnaire was pre-tested on $5 \%$ of the sample on similar population in one of the non-study kebeles. Based on the results of pretest, the time required for interviewing each participant was estimated and the skip pattern of some of the questions was corrected. The reliability of the items on attitude scale of the questionnaire was also tested using Cronbach's alpha after pre-test and a value superior or equal to 0.7 was considered as reliable. The Cronbach's alpha coefficient of attitude items was 0.75 .

The data were collected by eight female diploma nurses and the data collection was entirely supervised by two BSc Nurses. Furthermore, the data collection process was closely monitored by the principal investigators. Both data collectors and supervisors were trained for 2 days on the objectives of the study, sampling technique, data collection tool and techniques of collecting data to maintain precaution throughout the study. To reduce non-response or reporting biases, interviews were conducted either in private rooms or places where other people could not overhear. Daily meetings were also held between the principal investigators and enumerators to troubleshoot problems that arose in the data collection process. In addition, inspection for completeness and quality of data collection was carried out daily by the supervisors and feedback was provided to data collectors.

Married women's knowledge on LAPMs was assessed by asking 12 questions with 'yes/no' answers adapted from different literatures $[10,19,31]$. For each knowledge question a score of 1 was given to correct and 0 to incorrect responses. The final score was computed by summing all correct answers. Finally, to evaluate knowledge of the married women, it was categorized as "high" - for those who knew $70 \%$ and above, "moderate" - for those who knew 40 - $69 \%$ and "low"- for those who knew less than $40 \%$ of the total knowledge questions [31].

Married women's attitude towards LAPMs was assessed using 10 items rated on a five-point Likert scale adapted from different literatures [19, 31]. Attitude score was computed using the above 10 items whose theoretical value ranges from 10 to 50 . This scoring was subsequently reversed for negatively stated statements. Finally, respondents who scored above the median attitude score of the sampled population, which is 31 ,were labeled as having a positive attitude whereas respondents with an attitude score of less than or equals to the median score were labeled as having a negative attitude [31].

\section{Data processing and analysis}

Data were entered and cleaned using Epi- Info version 6.04, and transferred to SPSS 16 statistical software package for analysis. Descriptive analysis was used to describe the data. The dependent variables were desire for birth spacing or limiting, and LAPMs use. Desire for birth spacing or limiting was coded as 0 for women who have no desire for birth spacing or limiting and 1 for those who have desire for birth spacing or limiting. LAPMs use was coded as 0 for women who have desire for birth spacing or limiting and using LAPMs and 1 for those who have desire for birth spacing or limiting but not using LAPMs. Bivariate analysis was used to see the unadjusted effect of each factor on each of the dependent variables of the study. The independent variables with a $p \leq 0.05$ in the bivariate analyses with each of the dependent variables were fitted in to a multivariate logistic regression model to identify their independent effect on desire for birth spacing or limiting, and not using LAPMs among women who desire to space or limiting birth. Odds ratio with $95 \%$ confidence interval were calculated both to assess the association and measure the strength of the association between the explanatory and outcome variables.

\section{Results}

Socio-demographic characteristics of respondents

Out of the total 806 sampled married women, 779 women were included in the study with response rate of $96.7 \%$. The mean $( \pm \mathrm{SD})$ age of the respondents was $30.01( \pm 7.29)$ years. Majority of the respondents were Orthodox $(91.2 \%)$ in religion, house wives $(63.2 \%)$ in occupation and at least primary school $(77.7 \%)$ in education. The median monthly family income was 1000.0 ETB with a range of 250.0-5000.0 ETB (Table 1).

\section{Reproductive characteristics of respondents}

Out of the total respondents, 716 (91.9\%) had ever been pregnant. The median number of living children was 2 with 0 and 10 minimum and maximum alive children, respectively. More than two third, 539 (69.2 \%) didn't desire to have a child within the next 2 years. Pertaining to the fertility related decision making, $592(76.0 \%)$ reported joint decision making by both husband and wife 
Table 1 Socio-demographic characteristics of married women of reproductive age in Aksum town, North Ethiopia, 2015, ( $N=$ 779)

\begin{tabular}{|c|c|c|}
\hline Characteristics & Number & Percent \\
\hline \multicolumn{3}{|l|}{ Age } \\
\hline $15-24$ & 198 & 25.4 \\
\hline $25-34$ & 334 & 42.9 \\
\hline $35-44$ & 215 & 27.6 \\
\hline$\geq 45$ & 32 & 4.1 \\
\hline \multicolumn{3}{|l|}{ Religion } \\
\hline Orthodox & 711 & 91.2 \\
\hline Muslim & 66 & 8.5 \\
\hline Others $^{\mathrm{a}}$ & 2 & 0.3 \\
\hline \multicolumn{3}{|l|}{ Educational status } \\
\hline No formal education & 174 & 22.3 \\
\hline Primary & 280 & 36.0 \\
\hline Secondary & 229 & 29.4 \\
\hline Above secondary & 96 & 12.3 \\
\hline \multicolumn{3}{|l|}{ Occupation } \\
\hline House wife & 492 & 63.2 \\
\hline Merchant & 137 & 17.6 \\
\hline Employed $^{\mathrm{b}}$ & 97 & 12.4 \\
\hline Daily laborer & 36 & 4.6 \\
\hline Student & 17 & 2.2 \\
\hline \multicolumn{3}{|l|}{ Husband's educational status } \\
\hline No formal education & 182 & 23.4 \\
\hline Primary education & 261 & 33.5 \\
\hline Secondary education & 176 & 22.6 \\
\hline Above secondary education & 160 & 20.5 \\
\hline \multicolumn{3}{|l|}{ Husband's occupational status } \\
\hline Employed $^{\mathrm{b}}$ & 260 & 33.4 \\
\hline Merchant & 202 & 25.9 \\
\hline Daily laborer & 197 & 25.3 \\
\hline Farmer & 41 & 5.3 \\
\hline Private work & 37 & 4.7 \\
\hline Student & 30 & 3.9 \\
\hline Priest & 12 & 1.5 \\
\hline \multicolumn{3}{|l|}{ Monthly family income } \\
\hline$\leq 500 \mathrm{ETB}$ & 168 & 21.6 \\
\hline$>500 \mathrm{ETB}$ & 611 & 78.4 \\
\hline \multicolumn{3}{|l|}{ Regular media exposure ${ }^{c}$} \\
\hline Yes & 674 & 86.5 \\
\hline No & 105 & 13.5 \\
\hline
\end{tabular}

Table 1 Socio-demographic characteristics of married women of reproductive age in Aksum town, North Ethiopia, 2015, ( $N=$ 779) (Continued)

\footnotetext{
Visited and given health education on FP by HEWs

\begin{tabular}{lcc} 
Yes & 123 & 15.8 \\
No & 656 & 84.2 \\
\hline 1 USD $=20.95 \mathrm{ETB}^{\mathrm{a}}{ }^{\mathrm{a}}=$ protestant, catholic $^{\mathrm{b}}{ }^{\mathrm{b}}=$ both governmental and
\end{tabular}
}

on the number of children to bear. About 581 (74.6\%) of the respondents reported that they had discussed FP methods with their husband at least once in the past 6 months. Nearly three fourth $(72.5 \%)$ of the respondents believed that their husband approves the use of LAPMs. Moreover, majority $(70.4 \%)$ reported that they jointly decide with their husband on which type of contraceptive to use (Table 2).

\section{Knowledge and attitude of respondents}

Seven hundred forty seven (95.9 \%) of the total respondents reported that they had heard of LAPMs, and $578(74.2 \%)$ of them were familiar with at least one of the LAPMs. The most commonly known LAPMs was implant which account for 535 (71.6\%), followed by IUCD 433 (58.0\%). Major source of information about LAPMs was public health facilities 691 (92.5\%), followed by HEWs 553 (74\%). Generally, based on the composite scores of knowledge and attitude, $501(64.3 \%)$ of the respondents had moderate or high knowledge on LAPMs whereas half 390 $(50.1 \%)$ had positive attitude towards practicing LAPMs (Table 3).

Desire for birth spacing or limiting and not using long acting and permanent contraceptive methods

The total desire for birth spacing or limiting was $69.2 \%$; $35.8 \%$ for limiting and $33.4 \%$ for spacing. Of the total women who had desire for birth spacing or limiting, 80 $(14.8 \%)$ were using the method whereas the rest 459 (85.2 \%) women were not using LAPMs; $48.8 \%$ for spacing and $51.2 \%$ for limiting. The three main reasons cited by the respondents for not using LAPMs were fear of side effect 257 (56.0 \%), need for many children 83 (18.1 \%) and religious reasons 45 (9.8 \%) (Fig. 1).

\section{Factors associated with desire for birth spacing or limiting and not using long acting and permanent contraceptive methods}

Results of multivariate logistic regression analysis showed age, education, occupation; daily labor, regular media exposure, number of lifetime pregnancy, joint decision making on the number of children to bear and husband's attitude towards LAPMs use were positively associated with desire for birth spacing or 
Table 2 Reproductive characteristics of married women of reproductive age in Aksum town, North Ethiopia, 2015, ( $N=779)$

\begin{tabular}{lll}
\hline Characteristics & Number & Percent \\
\hline Number of pregnancy & 63 & 8.1 \\
None & 345 & 44.3 \\
$1-2$ & 233 & 29.9 \\
$3-4$ & 138 & 17.7 \\
$\geq 5$ & & \\
Number of abortion $(n=87)$ & 55 & 63.2 \\
1 & 32 & 36.8 \\
$\geq 2$ & & \\
Number of living children & 67 & 8.6 \\
None & 369 & 47.3 \\
$1-2$ & 244 & 31.3 \\
$3-4$ & 99 & 12.8 \\
$\geq 5$ & & 64.2 \\
Desire for more children & 500 & 35.8 \\
Yes & 279 & \\
No & &
\end{tabular}

Desired time for having additional child $(n=500)$

Within two years 240

After two years 260

Decider on when to have another child

Husband 13

Wife

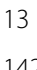

Both wife and husband jointly

$$
624
$$

Decider on number of children to bear

$\begin{array}{ll}\text { Husband } & 29 \\ \text { Wife } & 158 \\ \text { Both wife and husband jointly } & 592 \\ \text { Discussed FP methods with husband } & \end{array}$

$\begin{array}{lll}\text { No, never } & 198 & 25.4 \\ \text { Yes, once/twice } & 397 & 51.0 \\ \text { Yes, more often } & 184 & 23.6 \\ \text { Husband's attitude towards LAPMs use } & & \\ \text { Approve } & 565 & 72.5 \\ \text { Disapprove } & 59 & 7.6 \\ \text { Don't know } & 155 & 19.9 \\ \text { Decider on type of contraceptive to be used } & \\ \text { Husband } & 40 & 5.1 \\ \text { Wife } & 191 & 24.5 \\ \text { Both wife and husband jointly } & 548 & 70.4\end{array}$

limiting. That is, being $\geq 35$ years old $(A O R=2.10$, 95 \% CI: $[1.21,3.64])$, attending primary level of education $(\mathrm{AOR}=1.70,95 \% \mathrm{CI}$ : [1.09, 3.56]), being daily laborer in occupation $(\mathrm{AOR}=2.83,95 \% \mathrm{CI}$ : [1.02,
$7.87]$ ), being regularly exposed to media $(\mathrm{AOR}=2.03$, $95 \%$ CI: $[1.26,3.26])$, having $\geq 3$ lifetime pregnancy $(\mathrm{AOR}=1.73,95 \% \mathrm{CI}$ : $[1.15,2.60]$, joint decision making on the number of children to bear $(\mathrm{AOR}=2.43$, 95 \% CI: $[1.58,3.53])$ and unfavorable/unknown husband's attitude towards LAPMs use (AOR = 9.57, $95 \%$ CI: [4.91, 17.20]) were more likely to desire for birth spacing or limiting compared to their counterparts (Table 4).

However, the merchant category of the women's occupation variable was negatively associated with desire for birth spacing or limiting. That is, women who were merchants in occupation $(\mathrm{AOR}=0.52,95 \% \mathrm{CI}$ : $[0.34,0.79])$ were less likely to desire for birth spacing or limiting compared to housewives (Table 4).

Of the several factors included in the multivariate logistic regression analysis to identify factors associated with having desire for birth spacing or limiting but not using LAPMs, women's education, husband's attitude towards LAPMs, discussion on FP with husband, knowledge, attitude and intention to use LAPMs were positively associated with not using LAPM among women with desire for birth spacing or limiting. That is, women's education; secondary education $(\mathrm{AOR}=3.05,95 \% \mathrm{CI}:[1.18,7.85])$, not discussing family planning methods with husband (AOR =5.93, $95 \% \mathrm{CI}$ : $[3.61,8.77])$, low knowledge $(\mathrm{AOR}=$ 2.51, 95 \% CI: $[1.08,5.85])$, negative attitude towards LAPMs $(A O R=2.00$, 95 \% CI: [1.02, 3.87]), unfavorable/unknown husband's attitude towards LAPMs use $(\mathrm{AOR}=3.60,95 \% \mathrm{CI}:[3.06,5.84])$ and not intending to use LAPMs $(\mathrm{AOR}=7.70,95 \% \mathrm{CI}$ : $[4.18,14.17])$ were more likely not using LAPMs compared to their counterparts. However, women's occupation; daily labor $(\mathrm{AOR}=0.31,95 \% \mathrm{CI}$ : $[0.12,0.82])$ was negatively associated with LAPMs use (Table 5).

\section{Discussion}

In this study total desire for birth spacing or limiting was $69.2 \%$ (95 \% CI: 65.9, 72.4) which is higher than the total desire in developing region (57\%) [5]. However, it is lower than the 2011 EDHS report (75\%) [10] and a study in Ethiopia (77.8 \%) [21]. Of those who desire to space or limit births, $85.2 \%$ were not using LAPMs which is higher than the overall non-use of LAPMs in developing region (53 \%) [5] and study in Ethiopia $(62.9 \%)$ [13]. The inconsistency could be due to difference in time, socio-cultural and access to information and the services.

Age and number of lifetime pregnancy were positively associated with desire for birth spacing or limiting. Increasing age and number of lifetime pregnancy might let women have many children and met their fertility desire which results in desire for birth spacing or limiting and 
Table 3 Knowledge and attitude towards long acting and permanent contraceptive methods among married women of reproductive age in Aksum town, North Ethiopia, 2015

\begin{tabular}{|c|c|c|}
\hline Variables & Responses & $\begin{array}{l}\text { Number } \\
\text { (Percent) }\end{array}$ \\
\hline \multirow[t]{2}{*}{ Ever heard of LAPMs $(n=779)$} & Yes & $747(95.9)$ \\
\hline & No & $32(4.1)$ \\
\hline \multirow[t]{4}{*}{$\begin{array}{l}\text { aSource of information on LAPMs } \\
(n=779)\end{array}$} & $\begin{array}{l}\text { Public health } \\
\text { facilities }\end{array}$ & $691(88.7)$ \\
\hline & HEWs & $553(71.0)$ \\
\hline & Media & $489(62.8)$ \\
\hline & School & $122(15.7)$ \\
\hline \multirow[t]{2}{*}{ Know at least one LAPM $(n=779)$} & Yes & $578(74.2)$ \\
\hline & No & $201(25.8)$ \\
\hline \multirow[t]{3}{*}{ aType of LAPM known $(n=779)$} & Implants & $535(68.7)$ \\
\hline & IUCD & $433(55.6)$ \\
\hline & $\begin{array}{l}\text { Female } \\
\text { sterilization }\end{array}$ & $162(20.8)$ \\
\hline \multirow[t]{3}{*}{ Knowledge score (composite) } & Low & $278(35.7)$ \\
\hline & Moderate & $212(27.2)$ \\
\hline & High & $289(37.1)$ \\
\hline \multirow[t]{2}{*}{ Attitude score (composite) } & Negative & $389(49.9)$ \\
\hline & Positive & $390(50.1)$ \\
\hline
\end{tabular}

${ }^{a}$ Each of the percentages does not add up to 100.0 because respondents could choose several responses which could be spontaneous or prompted

use LAPMs $[13,16,17,19,20,26]$. Women's education was positively associated with both desire for birth spacing or limiting and use of LAPMs as shown in studies elsewhere [17, 18, 21, 24, 28, 29, 32]. This could be due to difference in awareness and health seeking behavior. Moreover, desire for birth spacing or limiting and not using LAPMs also varied with occupation $[17,18]$. This might be due to difference in socioeconomic status, access to information and women empowerment $[17,26,33]$.
Women with regular media exposure had higher desire for birth spacing or limiting compared to their counterparts similar to studies in Ethiopia [22]. Moreover, non-use of LAPMs varied with women's knowledge and attitude. Women with low knowledge on LAPMs were more likely not using LAPMs than their counterparts as shown in studies done in Ethiopia and Rwanda [15, 27]. Likewise, women who had negative attitude towards LAPMs were more likely not using LAPMs which was similar to studies in Ethiopia and Rwanda [17, 27]. This could be due to difference in health seeking behavior and acceptance of LAPMs.

Women who decide jointly with their husband on the number of children to bear were more likely to desire for birth spacing or limiting than their counterparts. Moreover, women who had no discussions about FP methods with their husbands were more likely not using LAPMs which is similar to studies elsewhere [12, $17,18,21,27,28,34]$. This could be due contribution of men's involvement and exchange of ideas on FP which leads to desire for birth spacing or limiting and LAPMs use [12, 16]. Furthermore, women having husbands with unfavorable/unknown attitude towards use of LAPMs were more likely to desire for birth spacing or limiting compared to their counterparts. This is consistent with studies in Ethiopia and Rwanda [13, 27]. Similar pattern of relationship was found between husband's attitude towards LAPMs and not using LAPMs as shown in studies elsewhere [12, 16, 17, 21, 27]. Having husband with unfavorable attitude towards LAPMs let women lack their husband's support in family planning and have too many or too close births, which results in higher desire for birth spacing or limiting.

This study has its own drawbacks. The study suffers from the usual limitation of cross sectional study. Moreover, it missed qualitative data and did not assess the contribution of health service related factors. It is still not free from social desirability and recall biases.

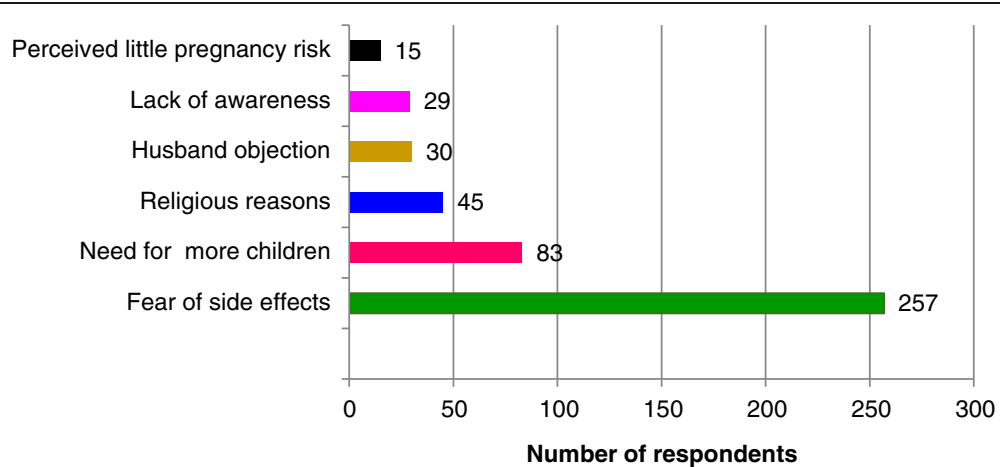

Fig. 1 Reasons for not using LAPMs among women of reproductive age who had desire for birth spacing or limiting in Aksum town, North Ethiopia, 2015 ( $N=539)$ 
Table 4 Factors associated with desire for birth spacing or limiting among married women of reproductive age in Aksum town, North Ethiopia, $2015(N=779)$

\begin{tabular}{|c|c|c|c|c|}
\hline \multirow[t]{2}{*}{ Variables } & \multicolumn{2}{|c|}{ Desire for birth spacing or limiting } & \multirow[t]{2}{*}{ COR $(95 \% \mathrm{Cl})$} & \multirow[t]{2}{*}{ AOR $(95 \% C l)^{a}$} \\
\hline & $\overline{Y e s}(n)$ & No $(n)$ & & \\
\hline \multicolumn{5}{|l|}{$\overline{\text { Age }}$} \\
\hline $\begin{array}{l}<25 \\
25-34 \\
\geq 35\end{array}$ & $\begin{array}{l}110 \\
234 \\
195\end{array}$ & $\begin{array}{l}88 \\
100 \\
52\end{array}$ & $\begin{array}{l}1 \\
1.87(1.30,2.70) \\
3.00(1.98,4.54)\end{array}$ & $\begin{array}{l}1 \\
1.46(0.97,2.20) \\
2.10(1.21,3.64)^{* *}\end{array}$ \\
\hline \multicolumn{5}{|l|}{ Education } \\
\hline $\begin{array}{l}\text { No formal education } \\
\text { Primary education } \\
\text { Secondary education } \\
\text { Above secondary education }\end{array}$ & $\begin{array}{l}130 \\
203 \\
150 \\
56\end{array}$ & $\begin{array}{l}44 \\
77 \\
79 \\
40\end{array}$ & $\begin{array}{l}2.11(1.24,3.59) \\
1.88(1.16,3.05) \\
1.36(0.83,2.21) \\
1\end{array}$ & $\begin{array}{l}1.97(0.85,3.43) \\
1.70(1.09,3.56)^{*} \\
1.48(0.84,2.60) \\
1\end{array}$ \\
\hline \multicolumn{5}{|l|}{ Occupation } \\
\hline $\begin{array}{l}\text { Daily laborer } \\
\text { Merchant } \\
\text { Employed } \\
\text { Student } \\
\text { Housewife }\end{array}$ & $\begin{array}{l}31 \\
80 \\
68 \\
8 \\
352\end{array}$ & $\begin{array}{l}5 \\
57 \\
29 \\
9 \\
140\end{array}$ & $\begin{array}{l}2.47(0.94,6.47) \\
0.56(0.38,0.83) \\
0.93(0.58,1.50) \\
0.35(0.13,0.94) \\
1\end{array}$ & $\begin{array}{l}2.83(1.02,7.87)^{*} \\
0.52(0.34,0.79)^{* *} \\
1.06(0.59,1.88) \\
0.45(0.16,1.22) \\
1\end{array}$ \\
\hline \multicolumn{5}{|l|}{ Regular media exposure } \\
\hline $\begin{array}{l}\text { Yes } \\
\text { No }\end{array}$ & $\begin{array}{l}480 \\
59\end{array}$ & $\begin{array}{l}194 \\
46\end{array}$ & $\begin{array}{l}1.93(1.27,2.94) \\
1\end{array}$ & $\begin{array}{l}2.03(1.26,3.26)^{* *} \\
1\end{array}$ \\
\hline \multicolumn{5}{|l|}{ Number of pregnancy } \\
\hline $\begin{array}{l}<3 \\
\geq 3\end{array}$ & $\begin{array}{l}243 \\
296\end{array}$ & $\begin{array}{l}165 \\
75\end{array}$ & $\begin{array}{l}1 \\
2.68(1.94,3.70)\end{array}$ & $\begin{array}{l}1 \\
1.73(1.15,2.60)^{* *}\end{array}$ \\
\hline \multicolumn{5}{|c|}{ Decider on number of children to bear } \\
\hline $\begin{array}{l}\text { Self/husband } \\
\text { Both wife and husband jointly }\end{array}$ & $\begin{array}{l}96 \\
443\end{array}$ & $\begin{array}{l}91 \\
149\end{array}$ & $\begin{array}{l}1 \\
2.78(1.98,3.91)\end{array}$ & $\begin{array}{l}1 \\
2.43(1.58,3.53)^{* * *}\end{array}$ \\
\hline \multicolumn{5}{|l|}{ Knowledge on LAPMs } \\
\hline $\begin{array}{l}\text { High } \\
\text { Moderate } \\
\text { Low }\end{array}$ & $\begin{array}{l}214 \\
150 \\
175\end{array}$ & $\begin{array}{l}75 \\
62 \\
103\end{array}$ & $\begin{array}{l}1.65(1.10,2.47) \\
1.46(0.99,2.15) \\
1\end{array}$ & $\begin{array}{l}1.36(0.86,2.15) \\
1.23(0.79,1.93) \\
1\end{array}$ \\
\hline \multicolumn{5}{|l|}{ Attitude towards LAPMs use } \\
\hline $\begin{array}{l}\text { Positive } \\
\text { Negative }\end{array}$ & $\begin{array}{l}284 \\
255\end{array}$ & $\begin{array}{l}106 \\
134\end{array}$ & $\begin{array}{l}1.41(1.04,1.91) \\
1\end{array}$ & $\begin{array}{l}1.18(0.80,1.72) \\
1\end{array}$ \\
\hline \multicolumn{5}{|c|}{ Ever use of modern contraception methods } \\
\hline $\begin{array}{l}\text { Yes } \\
\text { No }\end{array}$ & $\begin{array}{l}423 \\
116\end{array}$ & $\begin{array}{l}161 \\
79\end{array}$ & $\begin{array}{l}1.79(1.28,2.51) \\
1\end{array}$ & $\begin{array}{l}1.42(0.97,2.07) \\
1\end{array}$ \\
\hline \multicolumn{5}{|c|}{ Husband's attitude towards LAPMs use } \\
\hline $\begin{array}{l}\text { Approve } \\
\text { Disapprove/don't know }\end{array}$ & $\begin{array}{l}338 \\
201\end{array}$ & $\begin{array}{l}227 \\
13\end{array}$ & $\begin{array}{l}1 \\
10.42(5.80,18.72)\end{array}$ & $\begin{array}{l}1 \\
9.57(4.91,17.20)^{* * *}\end{array}$ \\
\hline \multicolumn{5}{|c|}{ Decider on type of contraceptive to be used } \\
\hline $\begin{array}{l}\text { Self/husband } \\
\text { Both wife and husband jointly }\end{array}$ & $\begin{array}{l}182 \\
357\end{array}$ & $\begin{array}{l}49 \\
191\end{array}$ & $\begin{array}{l}2.00(1.39,2.87) \\
1\end{array}$ & $\begin{array}{l}1.59(0.95,2.39) \\
1\end{array}$ \\
\hline
\end{tabular}

a adjusted for age, education, occupation, regular media exposure, number of pregnancy, decider on number of children to have, knowledge on LAPMs, attitude towards LAPMs use, ever use of modern contraception methods, husband's attitude towards LAPMs use and decider on type of contraceptive to be used *Significant at $P<0.05,{ }^{* *}$ significant at $P<0.01,{ }^{* * *}$ significant at $P<0.001$

\section{Conclusion}

This study revealed that there was high desire for birth spacing or limiting and not using LAPMs among women who had desire for birth spacing or limiting. Education, occupation, husband's attitude towards LAPMs, age, number of pregnancy, regular media exposure, and decider on the number of children to bear were significantly associated with desire for birth spacing or limiting. Moreover; education, occupation, husband's attitude towards LAPMs, discussion on FP with husband, knowledge, attitude and intention to use LAPMs were significantly associated 
Table 5 Factors associated with not using long acting and permanent contraceptive methods among married women of reproductive age who desire birth spacing or limiting in Aksum town, North Ethiopia, 2015, (N=539)

\begin{tabular}{|c|c|c|c|c|}
\hline \multirow[t]{2}{*}{ Variables } & \multicolumn{2}{|c|}{ LAPMs use } & \multirow[t]{2}{*}{ COR $(95 \% \mathrm{Cl})$} & \multirow[t]{2}{*}{ AOR $(95 \% \mathrm{Cl})^{\mathrm{a}}$} \\
\hline & No $(n)$ & Yes (n) & & \\
\hline \multicolumn{5}{|l|}{ Age } \\
\hline $\begin{array}{l}<25 \\
25-34 \\
\geq 35\end{array}$ & $\begin{array}{l}86 \\
201 \\
172\end{array}$ & $\begin{array}{l}24 \\
33 \\
23\end{array}$ & $\begin{array}{l}1 \\
1.70(0.95,3.05) \\
2.08(1.11,3.89)\end{array}$ & $\begin{array}{l}1 \\
0.75(0.35,1.60) \\
1.24(0.64,2.40)\end{array}$ \\
\hline \multicolumn{5}{|l|}{ Educational status } \\
\hline $\begin{array}{l}\text { No formal education } \\
\text { Primary education } \\
\text { Secondary education } \\
\text { Above secondary education }\end{array}$ & $\begin{array}{l}116 \\
170 \\
131 \\
42\end{array}$ & $\begin{array}{l}14 \\
33 \\
19 \\
14\end{array}$ & $\begin{array}{l}2.74(1.21,6.22) \\
1.72(0.84,3.50) \\
2.30(1.06,4.98) \\
1\end{array}$ & $\begin{array}{l}2.30(0.75,7.04) \\
1.87(0.73,4.84) \\
3.05(1.18,7.85)^{*} \\
1\end{array}$ \\
\hline \multicolumn{5}{|l|}{ Occupation } \\
\hline $\begin{array}{l}\text { Daily laborer } \\
\text { Merchant } \\
\text { Employed } \\
\text { Student } \\
\text { Housewife }\end{array}$ & $\begin{array}{l}22 \\
65 \\
57 \\
7 \\
308\end{array}$ & $\begin{array}{l}9 \\
15 \\
11 \\
1 \\
44\end{array}$ & $\begin{array}{l}0.35(0.15,0.81) \\
0.62(0.33,1.18) \\
0.74(0.36,1.52) \\
1.00(0.12,8.32) \\
1\end{array}$ & $\begin{array}{l}0.31(0.12,0.82)^{*} \\
0.69(0.33,1.44) \\
1.47(0.59,3.68) \\
1.38(0.12,15.55) \\
1\end{array}$ \\
\hline \multicolumn{5}{|c|}{ Decider on number of children to bear } \\
\hline $\begin{array}{l}\text { Self/husband } \\
\text { Both wife \& husband jointly }\end{array}$ & $\begin{array}{l}89 \\
370\end{array}$ & $\begin{array}{l}7 \\
73\end{array}$ & $\begin{array}{l}1 \\
2.5(1.12,5.59)\end{array}$ & $\begin{array}{l}1 \\
1.54(0.93,2.48)\end{array}$ \\
\hline \multicolumn{5}{|c|}{ Discussed FP methods with husband } \\
\hline $\begin{array}{l}\text { Yes } \\
\text { No }\end{array}$ & $\begin{array}{l}304 \\
155\end{array}$ & $\begin{array}{l}74 \\
6\end{array}$ & $\begin{array}{l}1 \\
6.25(2.66,14.69)\end{array}$ & $\begin{array}{l}1 \\
5.93(3.61,8.77)^{* * *}\end{array}$ \\
\hline \multicolumn{5}{|l|}{ Knowledge on LAPMs } \\
\hline High & 173 & 41 & 1 & 1 \\
\hline Medium & 124 & 26 & $1.13(0.66,1.95)$ & $1.44(0.76,2.72)$ \\
\hline Low & 162 & 13 & $2.95(1.53,5.71)$ & $2.51(1.08,5.85)^{*}$ \\
\hline \multicolumn{5}{|l|}{ Attitude towards LAPMs } \\
\hline Positive & 224 & 60 & 1 & 1 \\
\hline Negative & 235 & 20 & $3.15(1.84,5.39)$ & $2.00(1.02,3.87)^{*}$ \\
\hline \multicolumn{5}{|l|}{ Husband's attitude to LAPMs use } \\
\hline $\begin{array}{l}\text { Approve } \\
\text { Disapprove/don't know }\end{array}$ & $\begin{array}{l}275 \\
184\end{array}$ & $\begin{array}{l}63 \\
17\end{array}$ & $\begin{array}{l}1 \\
2.48(1.41,4.37)\end{array}$ & $\begin{array}{l}1 \\
3.60(3.06,5.84)^{* * *}\end{array}$ \\
\hline \multicolumn{5}{|c|}{ Decider on type of contraceptive to be used } \\
\hline $\begin{array}{l}\text { Self/husband } \\
\text { Both wife \& husband jointly }\end{array}$ & $\begin{array}{l}172 \\
287\end{array}$ & $\begin{array}{l}10 \\
70\end{array}$ & $\begin{array}{l}4.20(2.12,8.42) \\
1\end{array}$ & $\begin{array}{l}2.58(0.96,4.20) \\
1\end{array}$ \\
\hline \multicolumn{5}{|l|}{ Intention to use LAPMs } \\
\hline $\begin{array}{l}\text { Yes } \\
\text { No }\end{array}$ & $\begin{array}{l}156 \\
303\end{array}$ & $\begin{array}{l}63 \\
17\end{array}$ & $\begin{array}{l}1 \\
7.20(4.07,12.72)\end{array}$ & $\begin{array}{l}1 \\
7.70(4.18,14.17)^{* * *}\end{array}$ \\
\hline
\end{tabular}

${ }^{a}$ adjusted for age, education, occupation, decider on number of children to have, discussed FP methods with husband, Knowledge on LAPMs, husband's attitude to LAPMs use, decider on type of contraceptive to be used and Intention to use LAPMs

*Significant at $P<0.05,{ }^{*}$ significant at $P<0.01,{ }^{* * *}$ significant at $P<0.001$

with not using LAPM. In conclusion, findings from this study suggested the need to educate mothers on LAPMs with emphasis on those with higher number of children and lower educational status. The findings of this study also underlined the need for male involvement in FP program. Thus, the federal ministry of health and regional health bureau in combination with NGOs working on FP has to work hard to increase accessibility and availability of LAPMs in the study area.

\section{Abbreviations}

AOR: Adjusted odds ratio; Cl: Confidence interval; COR: Crude odds ratio; EDHS: Ethiopian Demographic and Health Survey; ETB: Ethiopian birr; FP: Family planning; IUCDs: Intrauterine contraceptive devices; LAPMs: Long acting and permanent contraceptive methods; NGOs: Nongovernmental Organizations; SD: Standard deviation

\section{Acknowledgements}

Aksum University is highly acknowledged for funding this research work. We are also grateful for the study community for providing us the necessary information. 


\section{Funding}

Aksum University is funder of this research work. The sponsor of the study had no role in study design, data collection, data analysis or interpretation, but did review this report prior to submission for publication. The corresponding author had full access to all the data in the study and had final responsibility for the decision to submit for publication.

\section{Availability of data and materials}

All the required data supporting the findings are contained within the manuscript.

\section{Authors' contributions}

KHM: conception, design, data analysis, drafting and writing final manuscripts. HBA, MGW: design, data analysis, drafting and writing final manuscripts. AAK, NBW \& YGT: design, data analysis and reviewing both draft and final manuscripts. GGA, TGG \&THG: design, and reviewing both draft and final manuscripts. All authors read and approved the final manuscript.

\section{Competing interests}

The authors declare that they have no competing interests.

\section{Consent for publication}

\section{Not applicable.}

\section{Ethics approval and consent to participate}

Ethical clearance was obtained from Research and Publication Center of Aksum University. Permission letter was also attained from Aksum town health office. Moreover, all study participants were informed about the purpose of the study and verbal consent was obtained from each study participant before data collection. Confidentiality was also ensured by using questionnaire identification number instead of using respondents' names.

\section{Author details}

${ }^{1}$ College of Health Science, Aksum University, P.O. Box 1010, Aksum, Ethiopia. ${ }^{2}$ College of Health Science, Addis Ababa University, Addis Ababa, Ethiopia. ${ }^{3}$ Tigray Regional Health Bureau, Mekelle, Ethiopia. ${ }^{4}$ Center of International Reproductive Health Training (CIRHT), Bahir Dar University, Bahir Dar, Ethiopia.

Received: 13 January 2016 Accepted: 2 November 2016

Published online: 15 November 2016

\section{References}

1. USAID. Long-acting and permanent methods of contraception: meeting clients' needs [Internet]. 2006. Available from: http://pdf.usaid.gov/pdf_docs/ pnadi070.pdf.

2. Long-Acting and Permanent Methods: Addressing Unmet Need for Family Planning in Africa - LAPM methods_English.pdf [Internet]. 2016. Available from: https://www.k4health.org/sites/default/files/LAPM\%20methods_ English.pdf. Accessed 20129 May 2016.

3. Trussell J, Guthrie K. Choosing a contraceptive: safety, efficacy, and personal considerations. In: Contraceptive technology. 20th rev ed. New York: Ardent Media; 2011

4. Jason B, Carl H, Marlene L, Mark M, Eric Z. World Population Highlights: key findings from PRB'S 2009 world population data sheet. Washington DC: Population Reference Bureau; 2009.

5. Singh S, Darroch JE, Ashford LS. Adding it up: The costs and benefits of investing in sexual and reproductive health. New York: Guttmacher Institute; 2014.

6. Ahmed S, Li Q, Liu L, Tsui AO. Maternal deaths averted by contraceptive use: an analysis of 172 countries. Lancet Lond Engl. 2012;380(9837):111-25.

7. Lith LMV, Yahner M, Bakamjian L. Women's growing desire to limit births in sub-Saharan Africa: meeting the challenge. Glob Health Sci Pract [Internet]. 2013;1(1):97-107. Available from: http://www.ghspjournal.org/content/1/1/ 97. Accessed 29 May 2016.

8. FP2020_Progress_Report_2013-2014_Digital_View_lores.pdf [Internet]. 2014. Available from: http://countryoffice.unfpa.org/pacific/drive/FP2020_ Progress_Report_2013-2014_Digital_View_lores.pdf. Accessed 28 May 2016.

9. Ali M, Cleland J. Determinants of contraceptive discontinuation in six developing countries. J Biosoc Sci. 1999;31(3):343-60.
10. EDHS. Demographic Health Survey 2011 Ethiopia Final Report.pdf [Internet]. 2011. Available from: https:/www.usaid.gov/sites/default/files/documents/1860/ Demographic\%20Health\%20Survey\%202011\%20Ethiopia\%20Final\%20Report.pdf. Accessed 28 May 2016

11. Population and Economic Development, 2012 Data Sheet - populationeconomic-development-2012.pdf [Internet]. 2012. Available from: http:// www.prb.org/pdf12/population-economic-development-2012.pdf. Accessed 26 Jul 2016

12. Takele A, Degu G, Yitayal M. Demand for long acting and permanent methods of contraceptives and factors for non-use among married women of Goba Town, Bale Zone, South East Ethiopia. Reprod Health [Internet]. 2012;9:26. Available from: http://dx.doi.org/10.1186/1742-4755-9-26. Accessed 29 May 2016

13. Bulto GA, Zewdie TA, Beyen TK. Demand for long acting and permanent contraceptive methods and associated factors among married women of reproductive age group in Debre Markos Town, North West Ethiopia. BMC Womens Health [Internet]. 2014;14:46. Available from: http://dx.doi.org/10. 1186/1472-6874-14-46. Accessed 28 May 2016

14. Yalew SA, Zeleke BM, Teferra AS. Demand for long acting contraceptive methods and associated factors among family planning service users, Northwest Ethiopia: a health facility based cross sectional study. BMC Res Notes [Internet]. 2015;8:29. Available from: http://dx.doi.org/10.1186/s13104015-0974-6. Accessed 28 May 2016.

15. Hailemariam A, Haddis F. Factors Affecting Unmet Need for Family Planning in Southern Nations, Nationalities and Peoples Region, Ethiopia. Ethiop J Health Sci [Internet]. 2011;21(2):77-89. Available from: http://www.ncbi.nlm. nih.gov/pmc/articles/PMC3275860/. Accessed 28 May 2016.

16. Haile A, Fantahun M. Demand for long acting and permanent contraceptive methods and associated factors among family planning service users, Batu town, Central Ethiopia. Ethiop Med J. 2012;50(1):31-42.

17. Korra A. Attitudes towards family planning and reasons for nonuse among women with unmet need for family planning in Ethiopia. [Internet]. 2002 [cited 2016 May 28]. Available from: http://dhsprogram.com/publications/ publication-fa40-further-analysis.cfm

18. Mota K, Reddy S, Getachew B. Unmet need of long-acting and permanent family planning methods among women in the reproductive age group in shashemene town, Oromia region, Ethiopia: a cross sectional study. BMC Womens Health [Internet]. 2015;15:51. Available from: http://dx.doi.org/10. 1186/s12905-015-0209-y. 28 May 2016.

19. Alemayehu M, Belachew T, Tilahun T. Factors associated with utilization of long acting and permanent contraceptive methods among married women of reproductive age in Mekelle town, Tigray region, north Ethiopia. BMC Pregnancy Childbirth [Internet]. 2012;12:6. Available from: http://dx.doi.org/ 10.1186/1471-2393-12-6. Accessed 28 May 2016.

20. Bhargava A. Desired family size, family planning and fertility in Ethiopia. J Biosoc Sci. 2007;39(3):367-81.

21. Mekonnen W, Worku A. Determinants of low family planning use and high unmet need in Butajira District, South Central Ethiopia. Reprod Health [Internet]. 2011:8:37. Available from: http://dx.doi.org/10.1186/1742-4755-837. Accessed 28 May 2016

22. Dibaba Y. Factors influencing women's intention of limit child bear. Ethiop Health Dev. 2008;22(3):28-33.

23. Getnet S, Abdrahman MA, Kemaw N. Long acting contraceptive methods utilization and associated factors among reproductive age women Arba Minch Town, Ethiopia. Greener Journal of Epidemiology and Public Health. 2014;2(1):023-31.

24. Ali AAA, Okud A. Factors affecting unmet need for family planning in Eastern Sudan. BMC Public Health [Internet]. 2013;13:102. Available from: http://dx.doi.org/10.1186/1471-2458-13-102. Accessed 28 May 2016.

25. Hosseini H, Torabi F, Bagi B. Demand for long-acting and permanent contraceptive methods among Kurdish women in Mahabad, Iran. J Biosoc Sci. 2014:46(6):772-85.

26. Palamuleni ME, Adebowale AS. Women empowerment and the current use of long acting and permanent contraceptive: Evidence from 2010 Malawi Demographic and Health Survey. Malawi Med J [Internet]. 2014;26(3):63-70. Available from: http://www.ajol.info/index.php/mmj/article/view/109518. Accessed 28 May 2016.

27. Demand and Unmet Need for Means of Family Limitation in Rwanda [Internet]. Guttmacher Institute. Available from: https://www.guttmacher org/about/journals/ipsrh/2009/demand-and-unmet-need-means-familylimitation-rwanda. 2009. Accessed 30 May 2016. 
28. Unmet Need and the Demand for Family Planning in Uganda - fa60.pdf [Internet]. 2008. Available from: http://dhsprogram.com/pubs/pdf/fa60/fa60. pdf. Accessed 26 Jul 2016.

29. Pebley AR, Delgado H, Brinemann E. Fertility Desires and Child Mortality Experience Among Guatemalan Women. Stud Fam Plann [Internet]. 1979; 10(4):129-36. Available from: http://www.jstor.org/stable/1965691. Accessed 26 Jul 2016.

30. Summary and Statistical Report of the 2007 [Internet]. Scribd. 2007. Available from: https://www.scribd.com/doc/37996909/Cen2007. Accessed 29 May 2016.

31. Meskele M, Mekonnen W. Factors affecting women's intention to use long acting and permanent contraceptive methods in Wolaita Zone, Southern Ethiopia: A cross-sectional study. BMC Womens Health [Internet]. 2014;14: 109. Available from: http://dx.doi.org/10.1186/1472-6874-14-109. Accessed 28 May 2016

32. Malwenna LI, Jayawardana PL, Balasuriya A. Effectiveness of a community based health education al intervention in reducing unmet need for modern meth ods of family planning among ever married reproductive age women in the Kalutara district, Sri Lanka. Int J Collab Res Intern Med Public Health. 2012;4(4):344-61.

33. Do M, Kurimoto N. Women's Empowerment and Choice of Contraceptive Methods in Selected Africatn Countries. Int Perspect Sex Reprod Health. 2012;38(3):23-33.

34. Agha S. Intentions to use contraceptives in Pakistan: implications for behavior change campaigns. BMC Public Health [Internet]. 2010;10:450. Available from: http://dx.doi.org/10.1186/1471-2458-10-450. Accessed 30 May 2016.

\section{Submit your next manuscript to BioMed Central and we will help you at every step:}

- We accept pre-submission inquiries

- Our selector tool helps you to find the most relevant journal

- We provide round the clock customer support

- Convenient online submission

- Thorough peer review

- Inclusion in PubMed and all major indexing services

- Maximum visibility for your research

Submit your manuscript at www.biomedcentral.com/submit 